Розділ І. Ціннісні орієнтири духовно-інтелектуального виховання, розвиток духовно-інтелектуальних якостей особистості в умовах співпраці й інклюзії

\title{
ПЕДАГОГІЧНА КАЗКА «МЕТОДИ ВИХОВАННЯ»
}

\author{
Рибалко Л. С. \\ доктор педагогічних наук, професор \\ професор кафедри освітології та інноваційної педагогіки,
}

Харківський національний педагогічний університет імені Г. С. Сковороди,

м. Харків, Україна

\section{Овсюк Д. Р.}

здобувач третього (освітньо-наукового) рівня вищої освіти кафедри освітології та інноваційної педагогіки,

Харківський національний педагогічний університет імені Г. С. Сковороди, м. Харків, Україна

У статті представлено досвід розробки та проведення педагогічної казки «Методи виховання» для здобувачів вищсої освіти. У розробленому сиенарії заходу викладена інформачія про методи виховання та запропоновані ситуачії для відпрацювання отриманих знань. Також надано приклад техніки самонавіювання для саморегуляиії у стресовій cumyauiï.

Ключові слова: методи виховання, методи формування свідомості, методи формування досвіду поведінки, методи стимулювання та корекиії поведінки, методи самовиховання, саморегуляиія.

The article presents the experience of developing and conducting a pedagogical fairy tale «Methods of education» for students of pedagogical education. The developed scenario of the event contains information about methods of education and suggested situations for testing the acquired knowledge. An example of self-suggestion technique for self-regulation in a stressful situation is also given.

Key word: methods of education, method of forming consciousness, method of forming the experience of behavior, method of stimulation and correcting behavior, method of self-education, self-regulation.

Важливість виховного компоненту освітнього процесу в роботі педагогічного працівника не піддається сумніву. Формування стійкого уявлення про методи виховання у здобувачів вищої освіти безперечно $€$ одним з важливих завдань професіоналізації майбутнього вчителя.

Мета статті - сформувати уявлення про методи виховання завдяки нетрадиційним формам організації освітнього процесу в закладах вищої педагогічної освіти. 
У підготовці сучасного здобувача вищої освіти для виконання ним професійної діяльності широко використовуються новітні методи та техніки навчання, зокрема ігровий та проблемний методи, які доповнюють та поглиблюють знання, отримані за допомогою традиційних методів навчання. Окрім того, в повсякденну професійну практику проникає все більше елементів психологічного знання, зокрема психологічні техніки та прийоми, за допомогою яких майбутній чи вже працюючий фахівець зможе оптимізувати власний емоційний та психологічний стани [1, с. 29]. Наведені вище чинники зумовили вибір форми заходу у вигляді педагогічної казки, в якій поєднані елементи ігрового та проблемного методів (у вигляді методу кейсів), використано наочний матеріал у формі презентації для занурення в атмосферу казки, а також включено таку психологічну техніку саморегуляції, як: самонавіювання, проєктивна методика, за допомогою якої здобувачі вищої освіти отримують інформацію про власний стиль та моделі поведінки в стресовій ситуації.

Сценарій заходу поділено на дві структурні частини. У першій, теоретичній, частині, здобувачам вищої освіти була надана основна інформація про методи виховання та за допомогою питань перевірено розуміння ними матеріалу. У другій, практичній, частині, здобувачі вищої освіти отримали змогу використати знання для розв'язання конкретних педагогічних ситуацій, а за допомогою проєктивної методики побачили свою поведінку у стресовій ситуації. При побудові сценарію заходу для зберігання структурної цілісності викладеного матеріалу було використано сюжет уявної подорожі, яка триває протягом дня.

Для кращого засвоєння інформації про основні групи методів виховання за Ю. Бабанським, а саме: методи формування свідомості, методи формування досвіду поведінки, методи стимулювання та корекції поведінки, методи самовиховання, названі методи виховання ототожнені з чотирма казковими князівствами. Для утворення відповідних асоціацій розповідь про кожне князівство, що умовно ототожнені з групами методів виховання, складалася з двох частин. У першій частині за допомогою розповіді та демонстрації слайдів описувався ландшафт кожного князівства (ліс, пагорби, гори, острів). Окрім встановлення асоціативних зв'язків між інформацією та наочністю, створювалася позитивна атмосфера заходу, котра налаштовувала здобувачів 
Розділ І. Ціннісні орієнтири духовно-інтелектуального виховання, розвиток духовно-інтелектуальних якостей особистості в умовах співпраці й інклюзії

вищої освіти до сприйняття навчальної інформації. Розповідалося про достеменність певного князівства, надавалася інформація про основні методи, які застосовуються у названій групі методів виховання. Наприклад, у лісовому князівстві Методів формування свідомості знаходиться достеменність - Храм Педагогіки, у якому слухач казки знайомився 3 техніками пояснення, навіювання, переконання та прикладу. За прослуханим матеріалом здобувачам вищої освіти ставили питання. Наприклад, у Храмі Педагогіки слухачам наводили слова В. О. Сухомлинського: «Боріться за думку і серце своїх вихованців» [2, с. 23] та пропонували висловитися стосовно змісту наведеної фрази.

Слід зазначити, що у випадку розповіді про групу методів самовиховання, слухачам була представлена психологічна техніка самонавіювання та наведені приклади, за допомогою яких майбутні педагоги зможуть створювати власні аффірмаційни вислови.

Для відпрацювання отриманих знань були представлені педагогічні ситуацій (фрагменти з казок «Дванадцять місяців (1956)», «Про Червону Шапочку (1978)», «Шрек» (2001)»). Кожну з педагогічних ситуацій треба було розв' язати за допомогою наведених у казці методів формування свідомості, формування досвіду поведінки, стимулювання та корекції поведінки. Здобувач вищої освіти міг використовувати тільки одну групу методів, або поєднувати їх залежно від власного бажання.

Наостанок слухачам була запропонована проєктивна методика «Людина під дощем» [1]. Зміст методики — намалювати людину під дощем. Мета методики - опосередковано визначити типову поведінку людини у стресовій ситуації. Інтерпретація методики можлива у індивідуальній (індивідуальна інтерпретація кожного малюнку ведучим) та колективній (ведучий оголошує, на що вказує розташування фігури, натиск ліній, окремі елементи малюнка) формі.

Досвід проведення заходу під час III осінньої школи Сковородинівської академії молодих учених виявив позитивне ставлення здобувачів II-III рівня вищої освіти до представленої форми роботи. Під час проведення в слухачів сформовано основні знання про методи виховання, які застосовувалися для вирішення наведених педагогічних ситуацій. Слухачі отримали навички саморегуляції в умовно створеній стресовій ситуації. Здобувачі вищої освіти зацікавилися ігровою формою заходу, активно включилися у вирішення запропонованих педа- 
гогічних ситуацій. Неабияку зацікавленість здобувачі вищої освіти виявили до проєктивної методики «Людина під дощем», яка була інтерпретована окремо для кожного слухача. Наскрізний сюжет про подорож, використання презентації створили позитивну доброзичливу атмосферу, яка сприяла засвоєнню наданих знань.

Отже, практичне значення педагогічної казки полягає у формуванні уявлення про методи виховання у здобувачів педагогічної освіти, їхніх умінь застосовувати набуті знання на практиці, застосовувати техніки саморегуляції у стресових ситуаціях.

\section{Список використаних джерел:}

1. Кільдеров Д. Е. Теоретичні і методичні засади забезпечення якості підготовки майбутніх учителів технологій на основі інтегрованого навчання : автореф. дис. ... д-ра пед. наук : 13.00.04. Вінниця, 2018. 42 с.

2. Сухомлинський В. О. Сто порад учителеві. Київ : Радянська школа, 1988. 304 c. C. 23

3. Проєктивна методика «Людина під дощем» Любахівська ЗОШ I-III ступенів Головна сторінка. URL: http://lubahiscool.at.ua/publ/poradi psikhologa/proektivna_metodika_ljudina_pid_doshhem/12-1-0-87 (дата звернення:07.10.2021) 